\title{
Thymoquinone Ameliorates Acute Kidney Injury Induced by Renal Ischemia-Reperfusion
}

\author{
La Timoquinona Mejora la Lesión Renal Aguda Inducida por Isquemia-Reperfusión Renal
}

Hend Ashour ${ }^{1,2}$; Laila Rashed ${ }^{3}$; Miran Atif Elkordy ${ }^{4}$ \& Omaima Mohammed Abdelwahed ${ }^{2}$

ASHOUR, H.; RASHED, L.; ELKORDY, M. A. \& ABDELWAHED, O. M. Thymoquinone ameliorates acute kidney injury induced by renal ischemia-reperfusion. Int. J. Morphol., 39(2):469-476, 2021.

SUMMARY: Renal ischemia-reperfusion injury (IRI)is an unavoidable consequence in renal transplantation and multiple clinical settings. A debate has been raised about the particular role of hypoxia-inducible factor $(\mathrm{HF}-1 \alpha)$ in the renal injury pathogenesis and the renal cortex ultrastructural alterations. Also, we investigated the antioxidant/anti-inflammatory effect of thymoquinone and its modulatory role on HIF- $1 \alpha$ in protection against renal IRI.Adult male Wister albino rats were assigned into 3 groups (n=16); 1) Sham-operated, 2) IRI model and 3) renal IRI pre-treated with thymoquinone $10 \mathrm{mg} \cdot \mathrm{kg}^{-1} \cdot \mathrm{day}^{-1}$ (TQ-IRI) for 10 days and at the reperfusion onset. Following the operation, 8 rats from each group were euthanized after 3 hours and the remaining 8 rats at 24 hours. Renal injury was assessed by the increased blood urea nitrogen, creatinine level, and the EGTI histological injury scoreat both 3 and $24 \mathrm{~h}$. HIF-1 $\alpha$ was upregulated $(\mathrm{p}<0.01)$ and was correlated with renal tissue reactive oxygen species (ROS) production and total oxidant capacity (TAC) consumption. Elevated inflammatory markers (NFkB, MCP-1 and VCAM-1) were associated with renal IRI.Thymoquinone treatment inhibited the accumulation of HIF- $1 \alpha(\mathrm{p}<0.01)$, reduced renal oxidation/inflammation process and markedly diminished renal injury.

KEY WORDS: Ischemia-reperfusion injury; Renal; HIF-1a; Thymoquinone.

\section{INTRODUCTION}

Ischemia-reperfusion (IRI) injury is a frequent clinical challenge induced by sudden temporary impairment of the blood flow to a particular organ. Acute kidney injury (AKI) induced by IRI is an unavoidable consequence in renal transplantation and multiple clinical settings. The pathophysiology of ischemic AKI is not fully understood. However, it is believed that, generation of vigorous oxidative stress and inflammatory mediators in response to hypoxia and re-oxygenation is the main core of tissue injury (Abdallah et al., 2018).

Hypoxia and inflammation are two dependent processes inducing cell injury during ischemia. Hypoxiainducible factor-1 (HIF-1 $\alpha$ ) is a vital transcription factor in cellular metabolic regulation in response to hypoxia (Choudhry \& Harris, 2018). During normoxic state, HIF$1 \alpha$ undergoes hydroxylation, destabilization and degradation. Meanwhile, hypoxic conditions prevent HIF- 1adestabilization, allowing its accumulation and nuclear translocation in order to induce the transcription of multiple protective genes (Shu et al., 2019). Therefore HIF-1 $\alpha$ participates in modulation of gene transcription to adapt cells for the hypoxic stressful conditions. However, HIF- $1 \alpha$ is a double-edged sword. A body of evidence supports the presence of a direct relation between HIF-1 $\alpha$ and the immune response activation (Cummins et al., 2016). Inappropriate HIF- $1 \alpha$ expression from renal tubuloendothelial cells is associated with macrophage activation and nuclear factor-kB (NFkB) expression. Indicating a link between hypoxia and the induced renal tubulointerstitial inflammation (Li et al., 2019).

Thymoquinone (TQ), 2-Isopropyl-5-methyl-1, 4benzoquinone, is one of the promising medicinal plants with various therapeutic benefits including anti-oxidant and antiinflammatory potential (Abuzinadah \& Ahmad, 2020; Abdel-

\footnotetext{
${ }^{1}$ Department of Medical Physiology, Faculty of Medicine, King Khalid University, Abha, KSA.

${ }^{2}$ Department of Medical Physiology, Faculty of Medicine, Cairo University, Egypt.

${ }^{3}$ Department of Biochemistry, Faculty of Medicine, Cairo University, Egypt.

${ }^{4}$ Department of Pathology, Faculty of Medicine, Cairo University, Egypt.

Laila Ahmed Rashed: 0000-0002-0362-1385

Miran Atif Elkordy:0000-0001-8570-1313

Omaima Mohammed Abdelwahed: 0000-0002-9899-5055
} 
Daim et al., 2020). The reno-protective effects of TQ have been demonstrated in various animal models of kidney diseases (Hammad \& Lubbad, 2016; Elsherbiny et al., 2017; Al Fayi et al., 2020). However, the regulatory role of thymoquinone on HIF-1ain renal IRI remains largely unknown.Our hypothesis was to study the mediating role of HIF- $1 \alpha$ in the 3 hours and 24 hours post renal reperfusion rat model and to evaluate the renal protective efficacy of thymoquinone against IRI, and its modulatory role on HIF-1a.

\section{MATERIAL AND METHOD}

Animals and ethical consideration. Forty-eight adult male Wister albino rats (150-170g body weight) were enrolled in the current study. The study protocol was approved by the institutional animal care and use guidelines of Cairo University (IACUC, \#:CU/III/F/22/20) according to the National Institutes of Health Guidelines. Rats were inbred and housed in normal light/dark cycles and maintained temperature at $\left(25 \pm 2{ }^{\circ} \mathrm{C}\right)$ with free access to water and standard rat chow.

Experimental design and study protocol. Following 2 days of acclimatization, the rats were allocated into 3 groups $(\mathrm{n}=16) ; 1)$ Sham operated group, 2) Renal ischemia reperfusion (IRI), and 3) rats exposed to renal IRI that were previously treated for 10 days with thymoquinone (TQ; Sigma-Aldrich, 274666) in a dose of $10 \mathrm{mg} \cdot \mathrm{kg}^{-1}$.day ${ }^{-1}$ intravenous, dissolved in DMSO. Administration of thymoquinone started 10 days before the induction of ischemia (TQ-IRI) and injected immediately after reperfusion. Following the operation, each group was divided into two subgroups; 8 rats were euthanized after 3 hours and the remaining 8 rats at 24 hours (the protocol is demonstrated in Fig. 1).

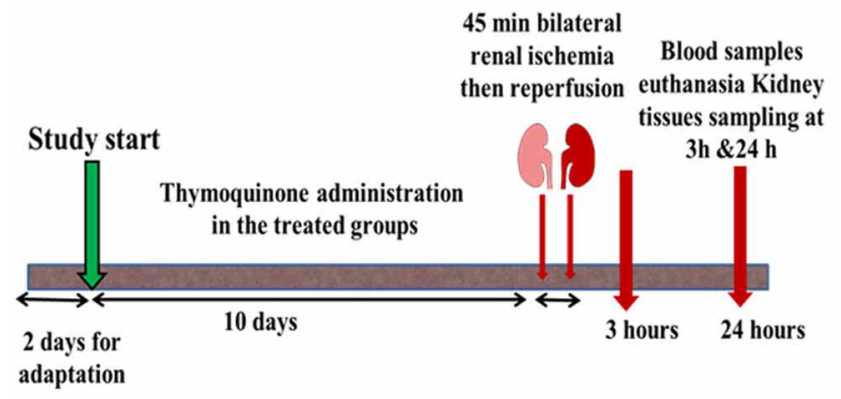

Fig. 1. Timeline for the experimental protocol.

Induction of bilateral renal IRI protocol. In brief, subcutaneous heparin 100U/Kg (Nile Co., Egypt) was injected to avoid renal vessel clotting during the ischemic phase. Rats then anesthetized by ketamine $50 \mathrm{mg} / \mathrm{kg}$ and xylazine hydrochloride 10mg/kg/i.p (Sigma, Egypt). Under aseptic precautions, a standard $3 \mathrm{~cm}$ midline laparotomy was performed. The intestines were retracted, and smooth clamps were placed carefully around both renal pedicles for $45 \mathrm{~min}$ during which the intestines were covered by a warm moist gauze to prevent dehydration. Afterward, the clamps were removed to allow reperfusion. The intestines were returned and the abdominal wall was sutured in layers. The sham group was subjected to the same operation procedures without renal pedicle occlusion.

Samples collection and preparation. At the indicated time either at 3 rd or the $24^{\text {th }}$ hour following reperfusion and under pentobarbital (50 mg/kg i.p.) anesthesia, blood samples were drawn from the abdominal aorta. The collected blood samples were left to be clotted then centrifuged at $3000 \mathrm{rpm}$ for 10 minutes for serum separation. The obtained serum samples were stored in $-20{ }^{\circ} \mathrm{C}$ till used for analysis.

\section{Biochemical analysis}

Renal functions estimation. Urea levels were estimated using the enzymatic colorimetric assay supplied by Biodiagnostics, Egypt, (\# UR 21 10), and for serum creatinine (\# CR 12 50).

Detection of oxidative stress and inflammatory markers in the renal tissues. Quantification of tissue oxidative stress and inflammatory markers in the right kidneys was conducted based on the technology of sandwich enzymelinked immune-sorbent assay. The used kits were supplied by (MYBioSource, Science and Technology Center, Egypt). Following the recommendations provided by the manufacturer, tissue homogenates were used for detection and quantification of HIF-1 $\alpha$ (\# MBS262533), ROS (\# MBS3807983), MCP-1 (\# MBS103250), VCAM-1 (\# MBS4503264) and NFkB (MBS268833). In brief, the used antibodies were pre-coated onto 96-well plates. The biotin-conjugated antibodies were added to form an immobilized immune complexes. The enzyme amount on the carrier is positively proportionate to the amount of the intended marker in the sample.

Total antioxidant capacity (TAC) Assay in the renal tissue. The Total Antioxidant Capacity Assay Kit (\# ab65329, Abcam, Kemet Medical, Egypt), was used according to the manufacturers recommendations.

Histological assessment. The left kidneys were collected, fixed in $10 \%$ buffered formalin and embedded in paraffin. Five $\mu \mathrm{m}$ sections were obtained, stained with hematoxylin and eosin (H\&E). Ten (HPF) were examined in each section to assess the histological damage in renal cortex affecting 
the endothelial, glomerular, tubular, and interstitial (EGTI) components according to the scoring system described by Khalid et al. (2016) with maximal total injury score of 14.

Statistical analysis. The collected data from were summarized as (Mean \pm SD). Using the Statistical Package for the Social Sciences (SPSS, version 20), the analysis of variance (ANOVA) test followed by Tukey's posthoc test was performed to detect the statistical difference between groups. EGTI scoring was analyzed by Kruskal-Wallis and Mann-Whitney tests and presented as median and interquartile range. Pearson correlation was done to test for linear relations between HIF-1aand other variables. A significant difference was considered if $\mathrm{p}$-value was $<0.05$.

\section{RESULTS}

Bilateral Renal IRI deteriorated renal functions and improved by thymoquinone. The measured blood urea nitrogen (BUN) and serum creatinine levels were increased markedly $(\mathrm{P}<0.001)$ following renal IRI at both $3 \mathrm{~h}$ and 24 $\mathrm{h}$ compared to the corresponding data of the sham group. The treatment with thymoquinone was accompanied by improved $(\mathrm{P}<0.001)$ renal functions at both $3 \mathrm{~h}$ and $24 \mathrm{~h}$ post-injury (Fig. 2)

Histological findings. EGTI scoring system of the renal cortex was assessed by light microscopic examination of the H\&E sections at (x 200, x 400), demonstrated damage of renal cortex at $3 \mathrm{~h}$ post-reperfusion (Figs. 3c,d). Loss of the brush margin of the tubular cells with focal necrosis (score 3 ) and glomerular tuft retraction (score 2)was detected. While tissue samples of IRI at 24h (Figs. 3i,j) showed cast formation and focal necrosis (score 3). Glomerular tuft retraction (score
2), inflammation and interstitial hemorrhage (score 1) compared to the normal cortical structure in the sham group (Figs. 3a,b,g,h). However, the signs of tissue injury were minimal by thymoquinone treatment at either duration. loss of tubular brush margin was less than $25 \%$, no cast formation or necrosis (Figs. 3e,f) and no damage/abnormality within the interstitial compartment (score 0) (Figs. 1 and 3k). Figure $3 \mathrm{~m}$ demonstrates the total EGTI score.

Renal ischemia-inducedHIF-1a expression and mitigated by thymoquinone. Renal IRI markedly $(\mathrm{P}<0.001)$ elevated the protein level of HIF-1a that was recorded at $3 \mathrm{~h}$ following reperfusion and maintained elevated to the 24th hour compared to the sham group at both durations. Thymoquinone diminished the HIF-1a induction when measured either at $3 \mathrm{~h}$ or $24 \mathrm{~h}$ post-reperfusion (Fig. $4 \mathrm{a}$ ).

Oxidative stress in the renal tissue of IRI group and suppression with thymoquinone. Disturbed renal tissue oxidation/reduction state was identified in the IRI group. The ROS content was increased following renal IRI, while the total antioxidant capacity was diminished compared to the sham $3 \mathrm{~h}$ and $24 \mathrm{~h}$ groups. Thymoquinone with its antioxidant potential fixed this disturbance, abrogated the elevated ROS levels, and restored the total antioxidant capacity (Figs. 4b,c).

Increased inflammatory markers by IRI and amelioration with thymoquinone. As expected, the inflammatory markers were upregulated in the renal tissue of the untreated rats. The levels of MCP-1, VCAM-1 and NFkBwere increased $(\mathrm{P}<0.001)$ following IRI at $3 \mathrm{~h}$ as well as at $24 \mathrm{~h}$ compared to the corresponding values of the sham group. Thymoquinone treatment for 10 days was effective in regulating pro-inflammatory markers and normalization of the VCAM-1 values were recorded at $3 \mathrm{~h}$ and at $24 \mathrm{~h}$ post-reperfusion (Fig. 5).

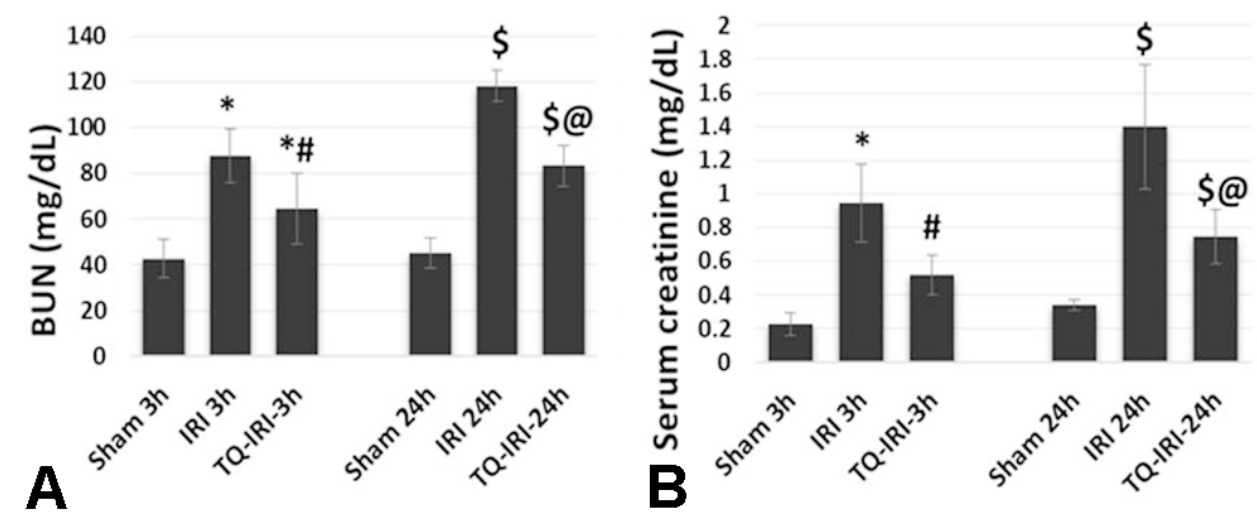

Fig. 2. Renal functions determination through assessment of a) serum creatinine and b) blood urea nitrogen (BUN). IRI: ischemia and reperfusion injury, TQ: thymoqinone. *: refers to significance to Shame 3h, \#: significant date compared to IRI-3h, \$ significance to IRI-24h and @ : refers to statistical significance to IRI-24h when $\mathrm{p}<0.05$. 


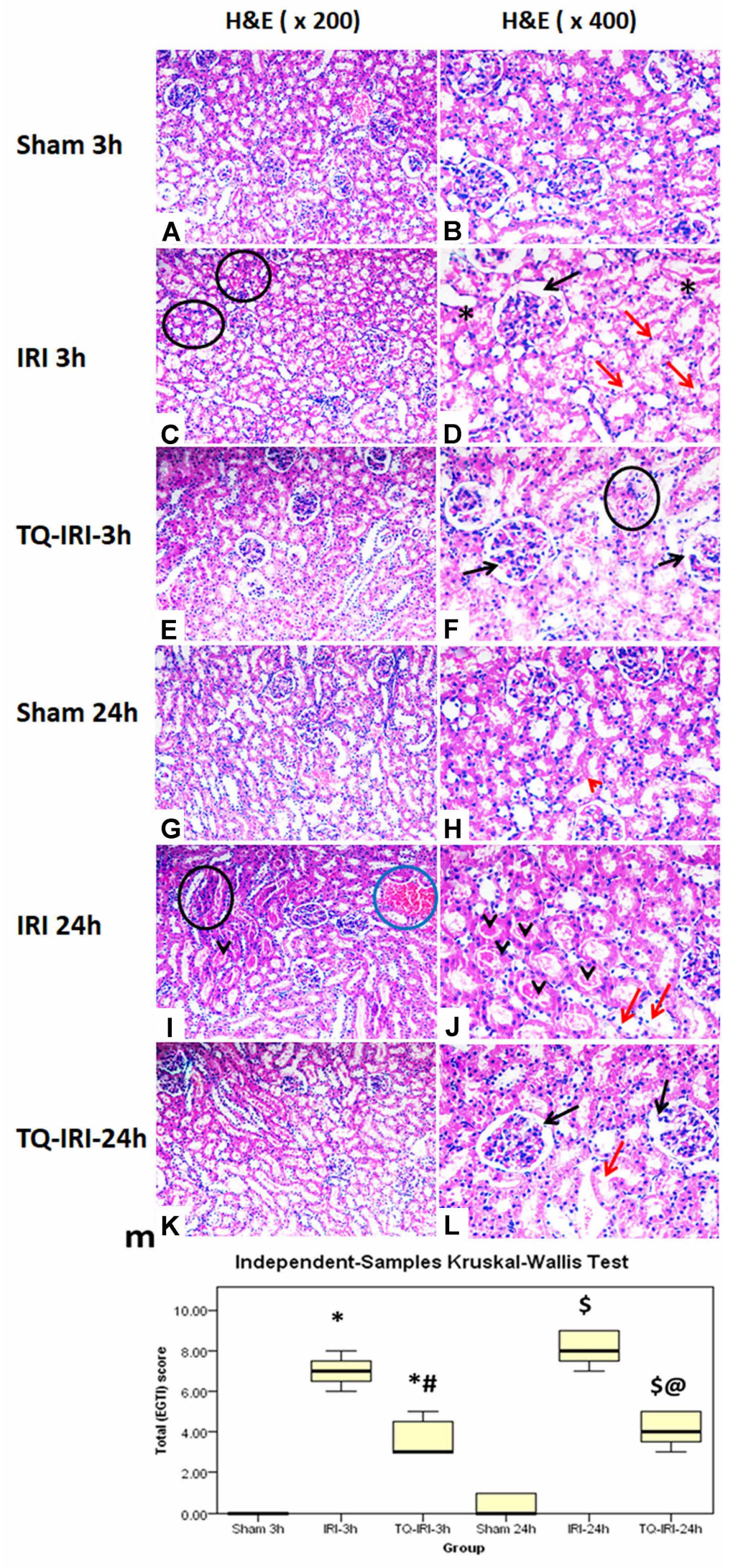

Correlations. We determined a close correlation between HIF-1 aand renal injury parameters; Creatinine $(\mathrm{r}=0.769, \mathrm{P}<0.001)$, BUN $(r=0.866, P<0.001)$, and the total EGTI score $(r=0.893, \mathrm{P}<0.001)$. In order to further support the link between HIF-1aand the oxidative stress, a strong positive correlation was detected between HIF1aandROS ( $\mathrm{r}=0.881, \mathrm{P}<0.001)$, whereas a negative association was determined to TAC $(\mathrm{r}=-0822, \mathrm{P}<0.001)$.Furthermore, the renal HIF-1awas positively proportionate to and the NFkB level $(\mathrm{r}=0.872, \mathrm{P}<0.001)$ (Fig. 6).
Fig. 3. Light microscopic histological findings in the renal tissue sections stained with H\&E (x 200 and $\mathrm{x}$ 400) magnifications. Images a \& b as well as $\mathrm{g} \& \mathrm{~h}$ demonstrate the normal cortical structure in the sham operated rats.Tissue injury manifestations are defined in the ischemia reperfusion injury groups (IRI) either at $3 \mathrm{~h}$ or 24 h. Thymoquinone (TQ) treatment mitigated renal tissue injury and decreased the histological injury findings. The black arrow: pointed to glomerular retraction, red arrow head: intact brush margin, while the red arrow: loss of brush margin. The black circle demonstrates interstitial inflammatory infiltrates, blue ones for interstitial hemorrhage. The black arrow heads: determine cast formation and the asterisk: shows areas of cellular necrosis. The total EGTI score represented by the median and interquartile range. $*$ : refers to significance to Shame $3 \mathrm{~h}$, \#: significant date compared to IRI-3h, \$ significance to IRI-24 h and @ : refers to statistical significance to IRI-24 h when $\mathrm{p}<0.05$. 


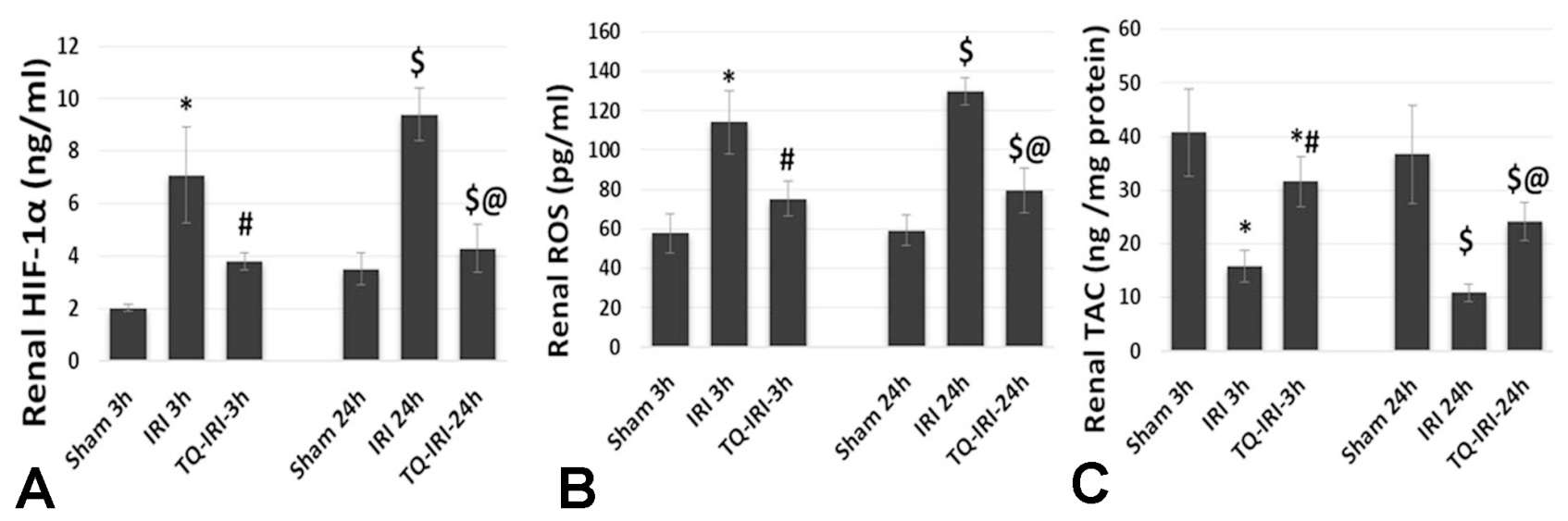

Fig. 4. a) HIF-1a: the hypoxia inducible factor level in the renal tissue, b) renal tissue reactive oxygen species (ROS) determination and c) the total antioxidant capacity (TAC) content in the kidney tissues. IRI: ischemia and reperfusion injury, TQ: thymoqinone. *: refers to significance to Shame 3 h, \#: significant date compared to IRI-3 h, \$ significance to IRI-24 h and @ : refers to statistical significance to IRI-24 h when $\mathrm{p}<0.05$.
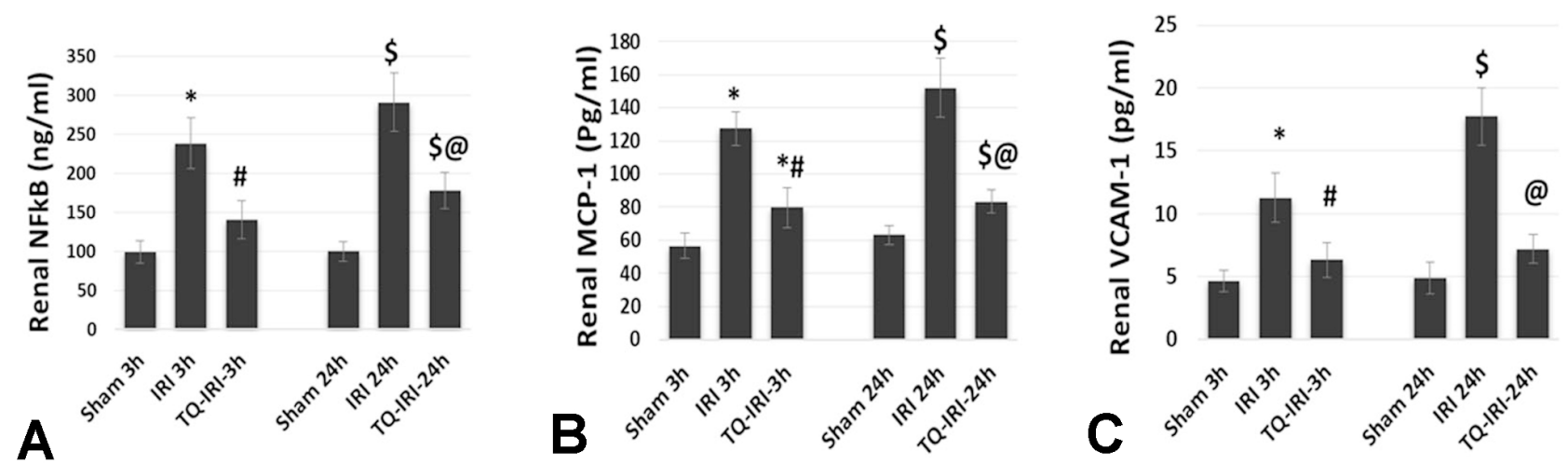

Fig. 5. Inflammatory markers determined in renal tissues. a) Nuclear factor (NFkB), b) monocyte chemo attractant protein (MCP-1) and c) vascular cell adhesion molecule (VCAM-1). IRI: ischemia and reperfusion injury, TQ: thymoqinone. *: refers to significance to Shame 3 h, \#: significant date compared to IRI-3 h, \$ significance to IRI-24 h and @: refers to statistical significance to IRI-24 h when $\mathrm{p}<0.05$.

\section{DISCUSSION}

The principal findings in our study were that HIFlawas induced and accumulated in the renal tissues of the ischemia-reperfusion injury (IRI) group. HIF- $1 \alpha$ was associated with the elevated serum creatinine and BUN biomarkers, as well as the total histological EGTI injury score. Thymoquinone treatment was valuable in diminishing the renal HIF- $1 \alpha$ and the oxidation/inflammation biomarkers. Consequently, improvement of renal functions and the renal tissue histological picture at both $3 \mathrm{~h}$ and $24 \mathrm{~h}$ post-reperfusion.

Cellular stress during renal ischemia upregulates HIF$1 \alpha$. Although the precise pathophysiology of renal IRI is unclear, HIF-1 $\alpha$ upregulation was associated with renal tubular damage (Li et al.). Several studies have emphasized the role of HIF- $1 \alpha$ in mitochondrial dysfunction generating ROS, and induced tissue injury (Bellanti et al., 2016; Ma et al., 2017). ROS generation mediates hypoxic renal tubular apoptosis and dysfunction. The results of Yildiz et al. (2010) study investigating renal ischemia for $45 \mathrm{~min}$ followed by reperfusion for 45 min caused significant renal function deterioration. They found an elevation of the total oxidant status (TOS), oxidative stress index (OSI), and myeloperoxidase (MPO) levels in the renal tissue and blood. These findings suggested that renal IRI enhances oxidative stress by modulating mitochondrial ROS generation and mitigating toxic cytokines production. 

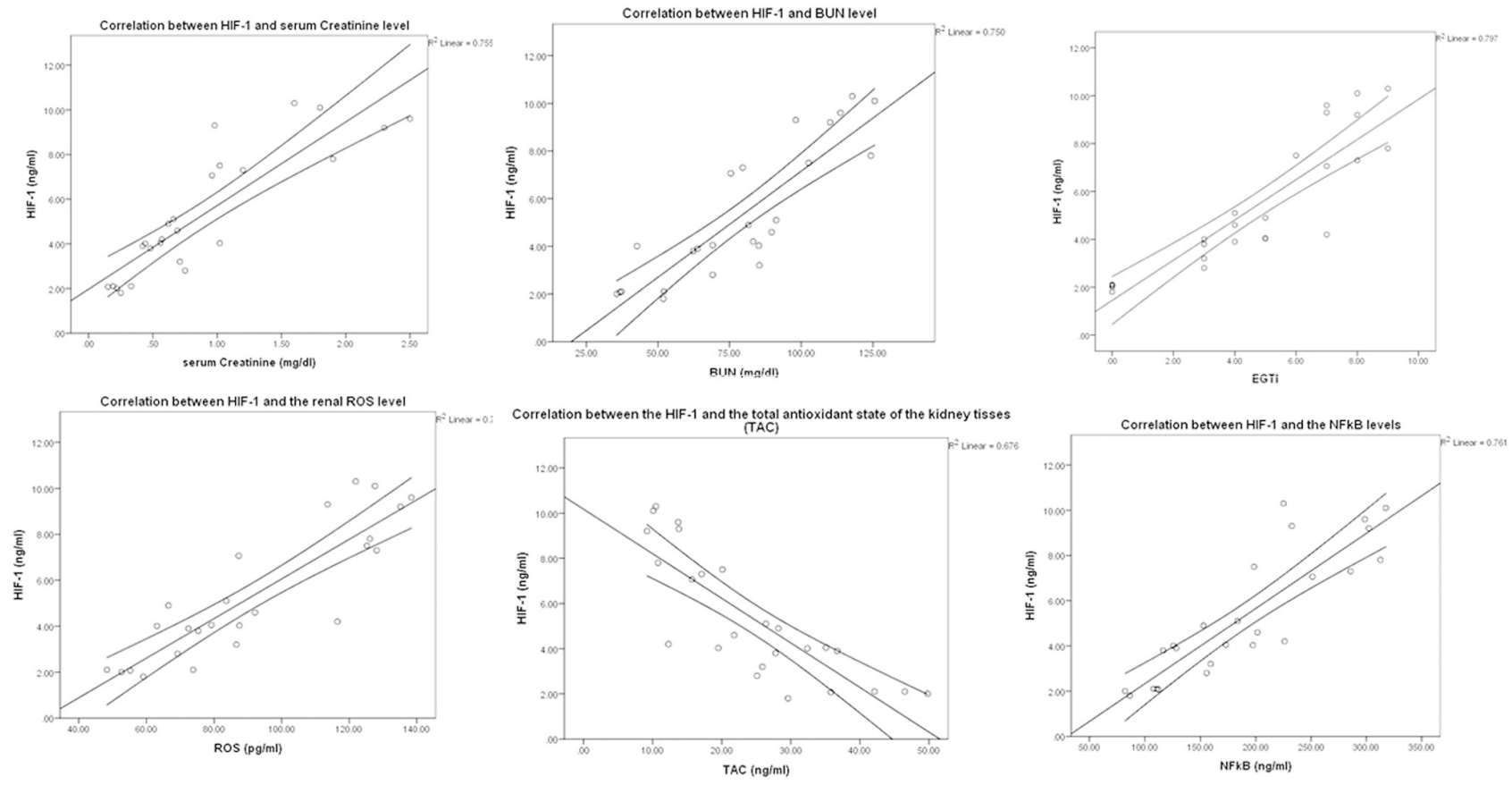

Fig. 6. Correlations between the hypoxia inducible factor (HIF-1) and a) serum creatinine, b)blood urea nitrogen (BUN), c) histological injury score, d) renal tissue reactive oxygen species (ROS) determination and e) the total antioxidant capacity (TAC) and f) Nuclear factor $(\mathrm{NFkB})$ in the renal tissue.

HIF- $1 \alpha$ is important for myeloid cell development and differentiation, and further, itpotentiates cell-mediated inflammation (Cramer et al., 2003). In the current study, we detected a strong positive correlation between renal tissue content of HIF- $1 \alpha$ and NFkB. Interestingly, the transcription factors NFkB and HIF molecular activation is interdependent (Cummins et al.). NFkB plays a role in HIF- $1 \alpha$ mRNA expression. During hypoxia, NFkB subunits bind to a specific site on the HIF- $1 \alpha$ promoter, stimulating HIF- $1 \alpha$ mRNA expression. In addition, mutation of this NFkB binding location on the HIF-1a promoter region abolished the hypoxic induction of HIF-1a (Belaiba et al., 2007). Furthermore, NFkB-related neutrophil survival is dependent on the HIF- $1 \alpha$ bioavailability (Walmsley et al., 2005). Taken together, acomplex interplay between HIF- $1 \alpha$ and NFkB is highly suggested in renal IRI pathogenesis. HIF- $1 \alpha$ and NFkB potentiate inflammatory cascades that are responsible for this form of hypoxia-inducedrenal tubulo interstitial inflammation (Li et al.). NFkB mediated renal interstitial inflammation through stimulating MCP-1 (Donadelli et al., 2000) and VCAM-1 expression (Pan et al., 2013). These data support the elevated renal tissue inflammatory mediators VCAM-1 and MCP-1 reported in the current study.

Growing evidence has acknowledged the renoprotective effect of the multitargeted molecule thymoquinone, depending on its anti-oxidant and anti- inflammatory anti-apoptotic potential (Hammad \& Lubbad; Elsherbiny et al.; Abuzinadah \& Ahmad; Abdel-Daim et al.; Al Fayi et al.). Thymoquinone was effective in reducing glomerular degenerative changes and decreasing the tubular necrosis score in a rat model of renal IRI injury. Thymoquinone diminished cellular vacuolation, interstitial edema, hyperemia, hemorrhage and tubular necrosis (Yildiz et al.; Mousavi, 2015). However, the precise modulatory role of thymoquinone on HIF- $1 \alpha$ activation in the setting of AKI has not been well addressed. These protective effects of TQ were previously explained, at least in part, by its antioxidant property and its ability to scavenge free radicals, protect cellular membranes against lipid peroxidation and increase the expression of tissue antioxidant genes. In line with our results, the treatment of rats with thymoquinone significantly ameliorated the renal oxidative stress indices. Thymoquinone inhibited malondialdehyde and enhanced glutathione and superoxide dismutase activities in renal tissues compared with the untreated IRI rats (Awad et al., 2011). The improvement of mitochondrial function and enhancing ATP production (Nagi et al., 2011) might be involved in its nephroprotective effects against oxidative tissue damage observed after acute renal IRI.

Furthermore, the anti-inflammatory potential of thymoquinone against renal injury has been characterized. Thymoquinone attenuated gene expression of a plethora of 
pro-inflammatory cytokines. Thymoquinone inhibited the activity of myeloperoxidase and NFkB-p65 in the renal cortical tissues, in which histological analyses showed less inflammatory infiltrate in kidneys of treated rats (Yildiz et al.; Mousavi).

In summary, the current work provides novel insights into the molecular mechanism of thymoquinone against renal IRI. We demonstrated that thymoquinone inhibited HIF1a and can effectively protect against acute kidney. The protective effect of thymoquinone was assessed by improvement of blood urea, creatinine, histological EGTI score, and biomarkers of inflammation and oxidative stress.

\section{ACKNOWLEGEMENTS}

The authors express their gratitude to the Deanship of Scientific Research at King Khalid University for providing funding this through the General Research Project grant (\# GRP-117-41).

ASHOUR, H.; RASHED, L.; ELKORDY, M. A. \& ABDELWAHED, O. M. La timoquinona mejora la lesión renal aguda inducida por isquemia-reperfusión renal. Int. J. Morphol., 39(2):469-476, 2021.

RESUMEN: La lesión por isquemia-reperfusión renal (IRR) es una consecuencia inevitable en el trasplante renal como también en múltiples contextos clínicos. Se ha suscitado una discusión referente a la relación particular del factor inducible por hipoxia $(\mathrm{HF}-1 \alpha)$ en la patogénesis de la lesión renal y las alteraciones ultraestructurales de la corteza renal. Además, investigamos el efecto antioxidante / antiinflamatorio de la timoquinona y su papel modulador sobre HIF-1 $\alpha$ en la protección contra IRR. Se utilizaron ratas albinas Wister macho adultas divididas en 3 grupos ( $\mathrm{n}=16)$; 1) Intervención simulada, 2) modelo IRR y 3) IRR pretratado con timoquinona $10 \mathrm{mg} / \mathrm{kg}^{-1}$.día ${ }^{-1}$ (TQ-IRR) durante 10 días y al inicio de la reperfusión. Posterior a la operación, 8 ratas de cada grupo fueron sacrificadas después de 3 horas y las 8 ratas restantes a las 24 horas. La lesión renal se evaluó por el aumento de nitrógeno ureico en sangre, el nivel de creatinina y la puntuación de lesión histológica EGTI tanto a las 3 como a las 24 horas. HIF- $1 \alpha$ se incrementó ( $p<0,01$ ) y se correlacionó con la producción de especies de oxígeno reactivo (ROS) del tejido renal y el consumo de capacidad oxidante total. Los marcadores inflamatorios elevados (NFkB, MCP-1 y VCAM-1) se asociaron con IRR. El tratamiento con timoquinona inhibió la acumulación de HIF-1 $\alpha$ ( $\mathrm{p}<0,01)$, redujo el proceso de oxidación / inflamación renal y disminuyó notablemente la lesión renal.

PALABRAS CLAVE: Lesión por isquemiareperfusión; Renal; HIF-1 $\alpha$; Timoquinona.

\section{REFERENCES}

Abdel-Daim, M. M.; Abushouk, A. I.; Bungau, S. G.; Bin-Jumah, M.; ElKott, A. F.; Shati, A. A.; Aleya, L. \& Alkahtani, S. Protective effects of thymoquinone and diallyl sulphide against malathion-induced toxicity in rats. Environ. Sci. Pollut. Res. Int., 27(10):10228-35, 2020.

Abdallah, N. H.; Baulies, A.; Bouhlel, A.; Bejaoui, M.; Zaouali, M. A.; Mimouna, S. B.; Messaoudi, I.; Fernandez-Checa, J. C.; García Ruiz, C. \& Abdennebi, H. B. Zinc mitigates renal ischemia-reperfusion injury in rats by modulating oxidative stress, endoplasmic reticulum stress, and autophagy. J. Cell. Physiol., 233 (11):8677-90, 2018.

Abuzinadah, M. F. \& Ahmad, A. Pharmacological studies on the efficacy of a thymoquinone-containing novel polyherbal formulation against cisplatin-induced hepatorenal toxicity in rats. J. Food Biochem., 44(2):e13131, 2020.

Al Fayi, M.; Otifi, H.; Alshyarba, M.; Dera, A. A. \& Rajagopalan, P. Thymoquinone and curcumin combination protects cisplatin-induced kidney injury, nephrotoxicity by attenuating NFkB, KIM-1 and ameliorating Nrf2/HO-1 signalling. J. Drug Target., 28(9):913-22, 2020.

Awad, A. S.; Kamel, R. \& Sherief, M. A. E. Effect of thymoquinone on hepatorenal dysfunction and alteration of CYP3A1 and spermidine/ spermine N-1-acetyl-transferase gene expression induced by renal ischaemia-reperfusion in rats. J. Pharm. Pharmacol., 63(8):1037-42, 2011.

Belaiba, R. S.; Bonello, S.; Zähringer, C.; Schmidt, S.; Hess, J.; Kietzmann, T. \& Görlach, A. Hypoxia up-regulates hypoxia-inducible factor-1alpha transcription by involving phosphatidylinositol 3-kinase and nuclear factor kappaB in pulmonary artery smooth muscle cells. Mol. Biol. Cell, 18(12):4691-7, 2007

Bellanti, F.; Mirabella, L.; Mitarotonda, D.; Blonda, M.; Tamborra, R.; Cinnella, G.; Fersini, A.; Ambrosi, A.; Dambrosio, M.; Vendemiale, G.; et al. Propofol but not sevoflurane prevents mitochondrial dysfunction and oxidative stress by limiting HIF- $1 \alpha$ activation in hepatic ischemia/reperfusion injury. Free Radic. Biol. Med., 96:323-33, 2016.

Choudhry, H. \& Harris, A. L. Advances in hypoxia-inducible factor biology. Cell Metab., 27(2):281-98, 2018

Cramer, T.; Yamanishi, Y.; Clausen, B. E.; Förster, I.; Pawlinski, R.; Mackman, N.; Haase, V. H.; Jaenisch, R.; Corr, M.; Nizet, V.; et al. HIF-1alpha is essential for myeloid cell-mediated inflammation. Cell, 112(5):645-57, 2003.

Cummins, E. P.; Keogh, C. E.; Crean, D. \& Taylor, C. T. The role of HIF in immunity and inflammation. Mol. Aspects Med., 47-48:24-34, 2016.

Donadelli, R.; Abbate, M.; Zanchi, C.; Corna, D.; Tomasoni, S.; Benigni, A.; Remuzzi, G. \& Zoja, C. Protein traffic activates NF-kB gene signaling and promotes MCP-1-dependent interstitial inflammation. Am. J. Kidney Dis., 36(6):1226-41, 2000.

Elsherbiny, N. M.; Maysarah, N. M.; El-Sherbiny, M. \& Al-Gayyar, M. M. Renal protective effects of thymoquinone against sodium nitrite-induced chronic toxicity in rats: Impact on inflammation and apoptosis. Life Sci., 180:1-8, 2017.

Hammad, F. T. \& Lubbad, L. The effect of thymoquinone on the renal functions following ischemia-reperfusion injury in the rat. Int. J. Physiol. Pathophysiol. Pharmacol., 8(4):152-9, 2016.

Khalid, U.; Pino-Chavez, G.; Nesargikar, P.; Jenkins, R. H.; Bowen, T.; Fraser, D. J. \& Chavez, R. Kidney ischaemia reperfusion injury in the rat: the EGTI scoring system as a valid and reliable tool for histological assessment. J. Histol. Histopathol., 3(1):1-7, 2016.

Li, Z. L.; Lv, L. L.; Tang, T.; Wang, B.; Feng, Y.; Zhou, L. T.; Cao, J. Y.; Tang, R. N.; Wu, M.; Liu, H.; et al. HIF-1a inducing exosomal microRNA-23a expression mediates the cross-talk between tubular epithelial cells and macrophages in tubulointerstitial inflammation. Kidney Int., 95(2):388-404, 2019.

Ma, Z.; Zhang, Y.; Li, Q.; Xu, M.; Bai, J. \& Wu, S. Resveratrol improves alcoholic fatty liver disease by downregulating HIF-1 $\alpha$ expression and mitochondrial ROS production. PLoS One, 12(8):e0183426, 2017. 
Mousavi, G. Study on the effect of black cumin (Nigella sativa Linn.) on experimental renal ischemia-reperfusion injury in rats. Acta Cir. Bras., 30(8):542-50, 2015.

Nagi, M. N.; Al-Shabanah, O. A.; Hafez, M. M. \& Sayed-Ahmed, M. M. Thymoquinone supplementation attenuates cyclophosphamide-induced cardiotoxicity in rats. J. Biochem. Mol. Toxicol., 25(3):135-42, 2011.

Pan, Y.; Zhang, X.; Wang, Y., Cai, L.; Ren, L.; Tang, L.; Wang, J.; Zhao, Y.; Wang, Y.; Liu, Q.; et al. Targeting JNK by a new curcumin analog to inhibit NF-kB-mediated expression of cell adhesion molecules attenuates renal macrophage infiltration and injury in diabetic mice. PLoS One, 8(11):e79084, 2013.

Shu, S.; Wang, Y.; Zheng, M.; Liu, Z.; Cai, J.; Tang, C. \& Dong, Z. Hypoxia and hypoxia-inducible factors in kidney injury and repair. Cells, 8(3):207, 2019

Walmsley, S. R.; Print, C.; Farahi, N.; Peyssonnaux, C.; Johnson, R. S.; Cramer, T.; Sobolewski, A.; Condliffe, A. M.; Cowburn, A. S.; Johnson, $\mathrm{N}$.; et al. Hypoxia-induced neutrophil survival is mediated by HIF1 $\alpha$-dependent NF-kB activity. J. Exp. Med., 201(1):105-15, 2005.

Yildiz, F.; Coban, S.; Terzi, A.; Savas, M.; Bitiren, M.; Celik, H. \& Aksoy, N. Protective effects of Nigella sativa against ischemia-reperfusion injury of kidneys. Ren. Fail., 32(1):126-31, 2010.
Correspondening author:

Dr/ Hend Ashour

Physiology Department Faculty of Medicine

King Khalid University

KSA \& Cairo University

Cairo

EGYPT

ORCID: 0000-0002-5423-7228

\author{
E-mail: hiahmad@kku.ed.sa \\ hend.a.hassan@kasralainy.edu.eg
}

Received: 28-08-2020

Accepted: 21-11-2020 